\title{
THE PASSING WORLD*
}

\author{
BY SIR HENRY TIZARD, K.C.B., F.R.S. \\ President of the British Association
}

$S^{\mathrm{E}}$

VEVENTY-SIX years have passed since the British Association met in Brighton. Great changes have taken place in the world since then. Nothing illustrates the lapse of time more strikingly than one passage in the address of the president, Dr. William Carpenter. After referring to the expedition sent for the relief of Livingstone he added :

"While we give a cordial welcome to Mr. Stanley, let us glory in the prospect now opening, that England and America will co-operate in that noble object which-far more than the discovery of the Sources of the Nile-our great Traveller has set before himself as his true mission, the Extinction of the Slave Trade."

And nothing better illustrates the truth of the old saying that the more things change the more they remain the same than the address of the president of the Section of Engineering, Mr. Bramwell. He discussed the coal problem. He directed attention to the alarming increase in the cost of coal, which had doubled in a year. "I am aware", he said, "that the subject of coal is a hackneyed one", but the startling facts to which he referred "force us seriously to reflect upon the use and also the abuse of coal." He discussed the inefficiency of domestic fires; but said he would rather put up with the whole of our present domestic discomforts, and even with the loss of heat than resort to the stove as a remedy. "But let not users of coal remain indifferent to savings on their present consumption until those improvements are discovered by scientifio men; on the contrary, let them forthwith do everything in their power to reduce the consumption to the extent to which present science and, in some instances, present practice show the consumption can be reduced."

At the same meeting the famous physiologist, Prof. Burdon Sanderson, referred to the backwardness of physiological research in Britain as compared with Germany. "If a man wants to be a physiologist", he said, "he must, as things at present stand, study medicine. There is no logical reason for this: for although medicine ought to be built on physiology, there is no reason why a physiologist should know anything about the art of curing diseases." However, it was a most encouraging sign of the times that Trinity College, Cambridge, had "condescended to provide a place for physiologists to study and labour in, from which ... one or two valuable researches have already sprung." We shall all agree that the condescension of Trinity College has been amply rewarded. There is perhaps still room for similar acts of condescension on the part of wealthy corporations.

There is, finally, another passage in Dr. Carpenter's address which is of special interest to me. He describes how he urged on his friends in the Admiralty the importance of organising a new expedition to circumnavigate the world, and how the Royal Society followed up his preliminary inquiries with a

* From the Presidential Address, delivered at Brighton, on September 8 . formal request. The Admiralty agreed, and the good ship Challenger was then fitting out at Sheerness, and being equipped with the most modern scientific apparatus. Captain Nares had been chosen to command the expedition, and Prof. Wyville Thomson to lead the scientific staff. The reason of my special interest is that my father was the navigating officer of that famous ship.

All that the British Association set out to achieve over a hundred years ago has been accomplished. Long past are the days when the public estimation of science had fallen so low that, to use the words of David Brewster in 1830, no scientist enjoyed "the favour of his sovereign, or the friendship of his ministers ;" and when an alarmed Dean of York was moved to publish a pamphlet entitled, "The Bible defended against the British Association", which attained such a popularity with Victorian churchgoers that it ran through five editions in one year. We men of science have little to complain of now. The public estimation of science stands higher than it has ever done in Great Britain. The Royal Society enjoys a prestige unequalled since the early part of the eighteenth century. The Great War, which has been succeeded by an uneasy peace, grimly demonstrated that the country whose rulers neglect science is lost; and public men in England now display a touching but alarming faith in the power of science to solve any national problem, however serious. The time is near when, as Huxley warned us over sixty years ago. science, like Tarpeia, may be crushed with the weight of rewards bestowed on her. Let us then beware, when all men speak well of us, and be critical of ourselves. Let us ask whether we are claiming too much in some directions, and doing too little in others; let us consider in fact whether the great forces of science, on the proper exercise of which all social progress depends, are in balance.

\section{The Progress of Sixty Years}

It was with some such thoughts as these that I chose the title of my address. It is taken from Dr. Johnson's well-known advice to the poor scholar in the "Vanity of Human Wishes."

"Deign on the passing world to turn thine eyes, And pause awhile from letters to be wise."

I propose to pause awhile from the fashionable discussions of Science and the Community, Science and Education, and the like, and to invite you to turn your eyes on the passing world. For it is passing -from one state of unstable equilibrium to another. I say unstable, for many many years will pass before the dreams of those who look forward to a world Government which will bring not only peace but also happiness to all, will come true. But if it must be in unstable equilibrium for many years to come, let us at least strive to balance it so that the chance of a major catastrophe is made as small as possible. Science has much to contribute to this aim ; but just as no man can aim a rifle accurately without a backsight as well as a foresight, so must we provide ourselves with both, if our contribution is to be worth 
while. The backsight is history ; it can be fashioned accurately by study. The foresight can only be fashioned from our knowledge of the state of science as it exists to-day, and from what we know is possible. It cannot be so accurate as we could wish, because we cannot foretell the effect of discoveries of which we have no inkling at present.

My backsight shall not be too far back. In considering the future we shall not gain more by studying remote history than we gain perceptibly in accuracy by lengthening the barrel of a rifle. I shall sight, somewhat arbitrarily, from the year 1885 ; not 1685 . It happens to be a convenient year for me, as it was the year of my birth. It happens, too, that it marks almost the close of the stagnant period of nineteenth century science, when many men thought that "ou $x$ power to discover new experimental facts was practically exhausted." But new men were coming on, and new ideas were hatching. J. J. Thomson had just been elected to the Cavendish chair of physics at the scandalously young age of twenty-eight -a thing which would not be tolerated nowadays. Charles Parsons had patented the steam turbine in 1884, and demonstrated a model at the Inventions Exhibition in 1885. Gowland Hopkins had been appointed assistant to $\mathrm{Sir} \mathrm{T}$. Stevenson, the Home Office analyst, and was studying, in his spare time, the pigments of the wings of butterflies. Three years were to pass before he was able to begin his formal education in science as a medical student at Guy's Hospital. Charles Sherrington was fighting cholera in Spain and investigating its causes, and Rutherford was carrying off all the prizes at school in New Zealand. Of these great men, whom many of us had the privilege of knowing, only one is alive to-day. Sir Charles Sherrington is the oldest living president of the British Association. We send him our respectful and affectionate greetings.

It is understandable that none of these events, which in their different ways were to have a more profound effect on history and society than any legislation, or rise or fall of governments, created any public interest, except perhaps the exhibition of the turbine which was considered ingenious but wholly unpractical. In other respects the events of the year 1885 followed a normal course, judged by modern standards. There was fighting in what we now call the Middle East, which ended in the massacre of British troops, and of their leader, General Gordon. Our Russian friends were told that anxious though we were to preserve our friendship, there was a limit to patience. But the British public soon recovered from the shock of Gordon's death, and refused, so far as I can judge, to be seriously disturbed by the prospect of war. It must be remembered that they were denied the blessings of broadcasting, and other modern equipment for the ready circulation of bad news. They were far more exercised by the prospect of cholera spreading from Spain. They had reason for their anxiety, for the great majority remembered the epidemic of 1866 when 14,000 deaths from cholera were recorded. On the whole, the people of England jogged along in a deplorable state of confidence, which was, however, justified by events, for nearly thirty years of peace followed, broken only by minor wars which had no perceptible effect on the growth of material prosperity.

In 1885, after a few years of depression, during which nearly 700,000 men and women left the country to seek better opportunities overseas, the United Kingdom was still the greatest manufacturing nation of the world. An enthusiastic commentator wrote at the time that "the material greatness of the country is amazing-it exceeds that of any other Empire, Ancient or Modern. But the moral greatness is even grander . . ." Unemployment was sometimes high in particular trades, such as shipbuilding, but between 1885 and 1914 it was never alarming, and was often as low as $2 \frac{1}{2}$ per cent of the gainfully employed. The United States were not then serious competitors; imports of iron and steel manufactures from the United States only reached an annual value of $£ 500,000$ in 1890 , but from then on steadily increased. Germany was considered a more serious competitor. In the pursuit of science she stood first among the nations, and she was applying the methods and results of scientific research to industry on a scale and with a determination that far surpassed her rivals. At the meeting of the British Association in 1885 the president, Playfair, sadly recorded that in science "Oxford and Cambridge are still far behind a second-class German University", and that "in Great Britain we have nothing comparable to the great technical college of Zurich". Germany kept her pre-eminence in applied science until 1914 ; but it is perhaps worth noting that she never equalled the industrial prosperity of England, judged by the test of real national income. She might have done so, had not her rulers believed that by war they could find $a$ short cut to the happiness and wealth that could have come in the natural course of events to a hardworking and highly educated people anxious to live in peace with the world. The terrible fate of Germany is a tragedy that affects us all, the last act of which perhaps we have not yet witnessed.

Many of the numerous comforts and luxuries which are now within the reach of every diligent working man in England are the result of invention or scientific discovery in or about the year 1885. I have already mentioned the steam turbine, which by making possible the generation of electricity on a large scale provided in the most convenient form the power on which industrial productivity so largely depends. Kelvin lit his house with electricity in 1881, and the telephone was invented in 1876; but they were both scientific curiosities in 1885. The modern 'safety' bicycle first appeared upon the roads in 1885 ; it was the manufacture of a reliable chain that made it practical. The first Dunlop pneumatic tyre appeared in 1888; but the idea was not then wholly new. Like many other things before and since, it had been invented before its time, that is to say, before manufacturing technique was sufficiently advanced to mako it practical. Edison, in 1885, was in the full tide of his inventive genius. The first talking machine had been demonstrated in 1877, and in 1885 he was busy experimenting with motion pictures. Swan, whose share in the production of the carbon lamp is well known, invented a practical process for the manufacture of artificial silk in 1883 . The typewriter in its early form was then quite old; but difficulties in manufacture prevented it from becoming available in quantity until towards the end of the century. The internal combustion engine which, in peace and war, has had a greater influence on society than any invention since that of printing, was developed from Otto's experiments in 1877 . The intrepid Daimler drove a bicycle powered by an internal combustion engine of his own design in 1885 ; and the first motor-cars were sold to the public. In the field of applied chemistry one far-reaching development to recall is the electrolytic production 
of aluminium in 1885. Aluminium was then a rare metal costing $£ 18$ a pound. It now costs $10 \mathrm{~d}$. a pound.

Thus, although the science of physics was languishing until the discovery of the electron, X-rays and radioactivity in the closing years of the century, it was a time of enterprise and progress in engineering practice. Britain prospered. In 1897, the year of the spectacular triumph of the Turbinia at Spithead, we exported goods to the value of one quarter of everything we produced. Ten years later we shipped overseas nearly one third of the whole national output of goods of all sorts- on farms, in mines, or in factories. If we were doing so to-day we should have little cause for anxiety. Perhaps it was this very prosperity that caused us to fall behind in some branches of industry, for when there is little unemployment and when the standard of living is obviously rising in all sections of the community, there is an excusable tendency for manufacturers to go on doing what they know they can do successfully, rather than to launch out in new directions. Is not this, rather than the neglect of science, the chief reason for the fact that synthetic dyes and fine chemicals were manufactured in Germany, rather than in their original home England? Whatever the answer to this question, the fact remains that when war started in 1914 we were caught off our balance. We found ourselves dependent on our enemies for many essential products and instruments on which our power to make war, and to maintain health, depended. But, to everyone's surprise, we also found that the reserve of scientific ability in the country, though not large, was high enough in quality to overcome the immediate dangers with remarkable speed. Young men from the universities who had spent their time on researches of no practical importance applied themselves with success to problems often completely outside the range of their previous studies. We had the same experience in the Second World War, although fortunately we also had the foresight to prepare for some of the worst dangers beforehand. There is a clear lesson, $I$ feel, to be drawn from this experience. Whatever may be done, in a burst of public enthusiasm, to support and promote schools of research at universities, nothing should be allowed to lower the quality; and size, beyond a certain point, undeniably does. A research laboratory, of whatever nature, is like a living cell. Once it reaches a certain size, which may differ with the nature of the subject, it must divide or die. When a young graduate tells me, as one did recently, that he was going to do research because it got him off military training, it makes me wonder whether we are not already overpopulating the research departments of universities.

The shock caused by the exposure in 1914 of our industrial shortcomings, which had been concealed by the apparent prosperity of previous years, led to a great increase of research by industry and by Government. The National Physical Laboratory, which had been of inestimable value during the War, extended the scope of its work. The Department of Scientific and Industrial Research, which was founded in 1915, established other Government research laboratories, and encouraged the formation of research associations to serve the needs of the older scattered industries. University schools of science were greatly enlarged, and under the influence of the great men of the inter-war period there was a surge of discovery which put Great Britain in the van of progress in nearly all branches of science. We became a scientific nation. The newer industries, such as the viscose and radio industries, which had been founded on science, rapidly developed. The chemical industries took on a new and active lease of life. Germany, badly disorganised by defeat, ceased for many years to be a serious competitor in the world market.

Many of us must have felt confident that when leadership in scientific and industrial research was allied to experience in commerce and manufacture, and to skill in craftsmanship, our country would have little difficulty in maintaining its position among the nations of the world. We have been disappointed. I am referring now not to the acute difficulties of the present day, but to the general trend of events before and after the First World War, when in spite of a nearly continuous advance in national income and standard of living, Great Britain gradually lost her pre-eminent position. We cannot attribute this relative decline to the 1914 War. That War had curiously little effect on our economy. Nor can we attribute it to the world depression in the 1930's. The depression affected us much less than many other nations, for owing to the great fall of prices of food and raw material the terms of trade moved sharply in our favour. During 1930-38 the volume of exports necessary to purchase a given volume of imports was only two thirds of what it had been during 1885-1914. To what then shall we attribute the relative decline? Shall we argue that a main cause was that research was on too small a scale, or shall we seek for other reasons?

\section{Research and Industry}

Let us first be clear about what results we expect to come from the application of science to industry. The primary object of industrial research is severely practical. It is not to enlarge the boundaries of knowledge, or to publish scientific papers, although that may be a prerequisite or a consequence. The object is to do something that has never been done before, or to do things better than they have been done before. And it has, or should have, the special object of reducing the labour required to supply the material needs and wants of men. All social progress such as spread of education, promotion of health, opportunities for leisure and healthy recreation, must depend on the power of science and technology to increase the productivity of industry. The rate of social reform is set by the rate at which productivity increases; and social unrest is inevitable if reform lags too far behind the advance of technology, or is pressed too thoughtlessly before it. So we must judge the effect of industrial research not merely by the new comforts and luxuries that it produces, but also by the rate of improvement of existing processes.

In Britain, which depends more than any other country on international trade, and which can con. tinue to maintain its present population only by exchanging manufactured articles for food and raw materials, the productivity of labour is of primary importance, for unless it is as high as, or higher than, in other manufacturing countries, we shall not be able to compete in the markets of the world. And the productivity of labour in Britain is far lower than it could $b e$ if the results of past research were more resolutely and continuously applied. We find this particularly in certain industries of great importance. In the coal industry the results are painfully obvious- 
the coal raised per man employed is now lower than it was thirty years ago, when nearly all coal was hewed by hand. Research on building has been intensively pursued since the Department of Scientific and Industrial Research was founded. Those responsible for its direction have not been content with the publication of papers giving the results of their investigations but have built demonstration houses for other builders to inspect and study. But are better houses now being built with less labour than twenty years ago? I doubt it; if not, the research has had as yet little influence on practice. The Shirley Research Institute for the cotton industry is well known for the range and excellence of its work; but productivity in the cotton textile trades is lower than it was fifteen years ago and much lower than in some other countries. Taking British industry as a whole, productivity is far lower than in the United States. In both countries about 40 per cent of the population is gainfully employed. In the United Kingdom the proportion engaged in manufacturing, building and civil engineering, which covers the production of all capital and consumer goods (other than minerals or food) is now a little less than 18 per cent of the population. In the United States the corresponding figure is 12 per cent ; and yet in proportion to the population the volume of production is far higher than in the United Kingdom.

The causes of the relative productivity and wealth of nations are, of course, many and complex. We gained our supremacy in the nineteenth century because we excelled in engineering genius and were the first to use mechanical power on the large scale for manufacture and transport. Our population grew rapidly because we were prosperous, and it paid us to become a food importing nation because the productivity of labour in the secondary industries was so much higher than in agriculture. But conditions have changed in the course of time. We no longer have any outstanding natural advantages, and we must expect that given approximately equal skill in technology other nations with greater natural advantages will surpass us. Only by maintaining leadership in the application of science can we hope to keep our position among the great nations. So it is not surprising that the United States, and Canada, for example, with their great natural resources, and abundant supply of cheap power, should have passed us in wealth and productivity before the War. It would have been surprising if they had not. But it is by no means so easy to explain why Switzerland, which in 1885 possessed a national income per head about two thirds of that of the United Kingdom, should have equalled us in prosperity by 1939 ; or why the industrial productivity of Sweden, a country that has no coal, should have been rising so much more rapidly than ours in the years between the wars. These two countries cannot be said to possess natural resources superior to ours; nor can it be argued that in the quality or quantity of scientific and industrial research they excel us. But $I$ suggest that they, in common with the United States, possess a higher average standard of technology than we do, and have a much greater proportion of men of high scientific education in executive control of industry. I quote them in support of my view that it is not the general expansion of research in Britain that is of first importance for the restoration of its industrial health, and certainly not the expansion of Government research remote from the everyday problems of industry. What is of first importance is to apply what is already known.

The fact is that all really new developments of industry are the product of the work of very few men. In general, knowledge in the physical sciences now accumulates at a rate much faster than it is, or possibly than it can be, applied in industry. There is a vast amount of knowledge waiting to be used. No new discovery, in any field, is likely to have so quick and beneficial an effect on British industry as the application of what is already known. We hear, for example, of the possibility of the production of power from atomic sources of energy. I do not think that anyone will be rash enough to prophesy what discoveries of real industrial importance will result from the researches now in progress ; but I shall certainly assert that the production of power from uranium cannot bring such economic benefits to Britain within twenty years as would the practical application of known methods of economizing coal. Mr. Bramwell's advice in $\mathbf{1 8 7 2}$ is still sound, and is always likely to be. Even in those fields of industy where science and development have been most in step, we find scientific knowledge far ahead of practice. In aeronautics, for example, research has shown, without any shadow of doubt, that it should be possible to design aircraft far more economical in fuel consumption than present aircraft. For the next step we need bold and highly skilled engineering rather than more fundamental knowledge: if it is successful, air transport, instead of existing precariously on subsidies, will compete on level terms with the train and ship for long-distance passenger travel. Indeed, a revolution in transport is in sight. Shall we leave it to be encompassed by other nations, or shall we show the way? The answer depends on whether we shall encourage enterprise and adventure in engineering.

\section{War as Applied Science}

Although I have been interested in the problems of industry for many years, I have never been closely concerned with its conduct. But for much of my working life I have been intimately concerned with that peculiar business called war, which is as old as agriculture, which is subject to the most violent booms and slumps, the cause of which we do not understand, and in which the incentive to succeed is greater than any profit or ideological incentive in civilian life. There is a healthy human rivalry between the various units and companies into which the business is divided. Sometimes it may be thought that this rivalry is carried too far ; but all are working for the same cause. In my own life-time I have seen this business change from one in which the practical man considered he had little to learn from scientists, into one in which scientists are concerned with its every aspect, from policy making to the actual conduct of operations. We shall all hope that this business is moribund, and shall do our best to kill it : but in the meanwhile it is possible that other old industries have much to learn by studying the principles of its successful conduct.

In the first place, let us note that the managing directors, the chiefs of staff and commanders, are all carefully selected highly trained professional men, who have gained their experience in a hard school, and who, at intervals in their career, have had the opportunity to study, at staff colleges and elsewhere, the fundamentals of their trade. The managing directors do not have the final responsibility for 
policy, but have a great influence on the decisions. Secondly, the technical efficiency of the business is entrusted to a body of engineers and technologists, who have had an advanced specialized education and experience, and who are in personal contact at all levels with scientists who are concerned with research and development. This secures that in all research, however recondite, there is a practical objective, and that there is also a continuous urge to improve in detail. The scientist is primarily responsible for research, but experienced engineers take part in it. The engineer and the scientist are jointly responsible for development. But there is no part in the whole process from research to production and use that is neglected, and none in which scientific thought and influence are wholly absent. One point of special interest is that far more attention-but perhaps still not enough-is given to the study of man in relation to the machines he has to operate than in any branch in industry.

It does not need any profound research to show that the British industries that are now best standing up to the strain of adverse circumstances are those that most nearly approach the system I have described. The chemical industries, for example, have gradually developed a similar organisation over the last thirty years. Neither research nor development has been neglected, and management is in the hands of men highly educated in pure and applied science. The result is that our chemical industries are a source of great and growing strength in peace and war. Forty years ago they were far inferior to the German industries; now they have little to fear from any competitors. In the steel industry, the efforts of which now merit our admiration, it is not uncommon to find management and direction entrusted to men of the highest reputation in science and technology. Turn your eyes on any industry in the world that is similarly organised, on the steel industry of Australia, for example, or the photographic industry of the United States, or the machine-tool industry of Switzerland, and you will find that they are the best able to weather the storms and take advantage of the fair winds of trade. Further, I shall ask you to note that in such industries human troubles, if not entirely absent, are inconspicuous. This, I think, is to be expected. for most men are happiest and do their best work when new things are being attempted, and when adventure of some kind relieves the monotony of a daily routine.

It is a mistake to suppose that science advances rapidly in a war. Certain branches of science may receive a special stimulus; but on the whole the advance of knowledge is slowed. What is striking in a war is the rapid solution of practical problems by the use of previously acquired scientific knowledge and technique. It is a mistake also to attribute this success to the fact that cost does not matter Cost matters a great deal ; indeed the purpose is always to achieve the end in view with the minimum cost of lives, labour and material. Finally, all depends on good design and production. Our weakness in the War was not to be found in the judgment of what was best to do, nor in the scientific work necessary to do it. It was when the stage of design and production was reached that we fell short of the best standards. The magnetron, which contributed more to the success of the Allies than any other single invention, was a product of British science ; but it had to be redesigned in the United States for economical manufacture. Penicillin, the greatest practical achievement of medical research during the War, also originated in Britain, but unless American skill in large-scale manufacture had been available, many thousands of men, who now enjoy a healthy life, would have died.

We now see history repeating itself. After the Second World War, as after the First, there is a cry for more research, in industry, and by Government, and a strong demand on the universities to expand their schools of science. Temporarily this enthusiasm is having an unfortunate effect, for the schools are getting starved of teachers; and unless a high standard of teaching is maintained in our schools, the next generation of scientists will suffer. In the long run, too, the expansion of research will fail to produce the hoped-for result unless we promote at the same time education in the higher branches of technology, and unless the technologist takes his rightful place in industry. Throughout the nineteenth century, the advances in engineering that made so great a difference to our prosperity, were the product of inventive rather than of scientific genuis. Even the steam turbine, though its conception was founded on long-established physical principles, was brought to a high pitch of practical efficiency with very little assistance from scientists. But we live in a different age. Pure invention still has its place; but industrial prosperity will depend more and more on the continuous application of science to industrial practice. Unless we can raise our standard of tech. nology, unless there are many more men in executive positions in industry whose practical experience has been preceded by a scientific eduction, we shall inevitably fail to keep our place among the great manufacturing nations. President Playfair's remark about Oxford and Cambridge is no longer true. Cambridge has long been recognized throughout the world as a great home of science ; and it is not merely devotion to my Alma Mater that prompts me to say that Oxford is now not far behind. But I fear that it is still true that in Britain we have nothing comparable to the great technical college in Zurich.

\section{Advances in Public Health}

I turn now to another branch of applied science, less spectacular in its results to the ordinary citizen, but far greater in the benefits that it has brought to mankind during the last sixty years. The physical sciences have given men comforts and luxuries that are obvious to all. The aeroplane, the cinema, the broadcasting and television receiver, the domestic refrigerator, and many other familiar things which were unknown even at the end of the nineteenth century, are positive results of scientific research. Health, on the other hand, is in a different category. The ordinary citizen sees little connexion between the advance of seience and the fact that he is healthy; it is, he feels, a quality that other people may lack, but is his by right of a superior heredity or habit. Ill health, on the other hand, while a fault in other people, is a misfortune in himself, and a serious reflexion on the state of medical science. How many men now living in Britain have any real conception, I wonder, of the astonishing advances in the prevention and cure of disease that have taken place in the last sixty years, and of how they have come about? Where is the cholera with which I was threatened as a child if I drank unboiled water ? Its last appearance in England was in 1893; it was soon stamped out, and there has been no epidemic since. We are puzzled and alarmed by its appearance even in a country like Egypt, with its low standard of sani- 
tation. Many other diseases which were common in 1885 have practically disappeared or are under control. Those that remain, will, without doubt, be conquered in the end by the advance of knowledge.

In 1885 the crude death-rate was twenty per thousand; now it is twelve. In 1885 one in every seven children died during the first year of life; now the figure is one in twenty-five. In 1885 a young man of twenty could expect on the average to live for fortyone years; now his expectation of life is forty-eight years. And it is not merely that he will have a longer existence, but that he can look forward to a far healthier life. Where can one now find the stunted children with distorted limbs, who were a common sight in the industrial towns of England when I was young ? If it were possible to compare a random sample of young men and women from the poorer districts of London with their grandparents at the same age, it could scarcely be believed that they came from the same stock. Only those few medical men who had the duty of examining recruits for the Army in the First and the Second World Wars can have any vivid appreciation at first hand of the changes that have come about in a single generation through the study of nutrition and preventive medicine.

These great advances have been mainly due to the fundamental researches of very few men, and to the vigour and good judgment with which their work has been extended and applied in practice. Never has public money been better spent than on this branch of applied seience; and never has such a small investment yielded such a rich return to the nation. The recently published report of the Medical Research Council, covering the war years $1939-45$, is a document of the highest scientific and historic importance which can be read with interest and profit even by laymen who are unfamiliar with the jargon of medical men. In 1939 the Medical Research Council confidently stated that:

"The destructive power of arms will indeed have increased immensely since 1918 if it overshadows the advances in knowledge for the saving of life which modern discovery has placed at the disposal of medical men. If a strict comparison were made between what science has done to increase war mortality and what medical science has done to lessen these lethal effects, there is good reason to believe that the latter would be an easy winner."

Omit the word 'medical' in the last sentence, and I think it will be agreed that no prediction has been more amply justified. Nor should we too quickly assume that new destructive weapons evolved by physical science will in the future reverse the decision. In spite of all the hazards of bombing, the average civilian death-rate during the years of war was lower than it was during the immediately preceding years of peace. The deaths in the fighting services were less than one third of the deaths in the 1914-18 War; and more than 80 per cent of the wounded have been restored to normal life. In spite of all the difficulties caused by the submarine blockade, and the shortage of food, which still persists, we are a healthier nation than we were in 1939. Whether we are as energetic is another question.

Our American allies have the same tale to tell. Four years of hard fighting in Europe and the Pacific caused fewer deaths than in the American Civil War, when the population of the United States was only one fourth of what it is now. It was only in
Germany, East Europe and the U.S.S.R. that war counted its victims by millions, and then not through the destructive forces of science, but because of the brutality of human nature at its worst

Nevertheless, the progress of preventive medicine is giving rise to social changes of great complexity, which will seriously affect the peace and prosperity of the world unless their consequences are studied with care, and their possible evils counteracted by wise and far-sighted action. In all countries which have a high standard of education, such as our own, the rise in population which follows a rapidly decreasing death-rate has been kept in check by a voluntary control of births. As a result the average age of the population has considerably increased, and is increasing; the proportion of the population of England and Wales that is more than sixty-five years of age is now nearly four times as high as it was in 1885. This in itself does not yet present any serious problem, for, as the proportion of children is much less than it was, the proportion capable of productive work, between the ages of fifteen and sixty-five, is actually somewhat higher than in 1885 . No fundamental difficulty, from this cause, is likely to arise for many years to come. But the population of the world as a whole is now increasing by 1 per cent a year, and its distribution is such as to make it extremely doubtful whether the supply of food can keep pace, even with the present low standard of nutrition. It is the advance of science that has made this possible. War, pestilence, and famine have kept the population within bounds since the dawn of history. War has ceased to be effective; pestilence is rapidly losing its power; only famine is left as a brake until education takes its place. Is famine inevitable, or will science again come to the rescue, as it has done before? I do not think that the danger of the present position is yet fully realized, in spite of all the work and publications of the United Nations Organisation, and in our country the well-informed denates and warnings of the House of Lords. People remember only too well the apparent over-production of food in the 1930's, and forget, or do not know, that since then the population of the world has increased by some 300 million people.

A single example of what is now happening, and will probably happen on an ever-increasing scale, may help to illustrate the problem. Malaria has always been one of the most potent instruments of population control. It is endemic in most tropical countries. In the Far East it has hitherto been an antagonist more to be feared than the armed forces of an enemy. In the Second World War it was defeated by the controlled use of 'Mepacrine', a German drug, which is being replaced by an even better product of British research. In addition, the potential importance of the insecticide D.D.T. for the elimination of malaria-carrying mosquitoes began to be recognized toward the end of the War.

In 1944, Sir Robert Robinson, Prof. J. L. Simonsen, and Dr. Harold King visited British Guiana on a special mission. British Guiana has a population of roughly 400,000 . Accurate statistics of the fluctuation of population do not exist; but it is probable that it has remained stationary for the last twenty years. Two thirds of the population used to live under conditions of severe endemic malaria. The birth-rate was low, and the infantile and adult mortality high.

The particular type of mosquito which is the varrier of malaria, and also of yellow fever and filariasis in 
the Colony, lives and breeds in the wooden houses, and not in swamps. It is thus peculiarly susceptible to attack by insecticides. The British mission advised a comprehensive trial. They were fortunate in finding a most experienced and progressive officer in Dr. Giglioli, honorary Government malariologist. Their advice was taken; operations were started in 1945, and at the time of speaking it is probable that the whole population of the Colony has been protected. The annual cost of keeping the whole district under continuous control is of the order of five shillings a head.

Malaria is now rapidly disappearing from the Colony. I cannot quote valid statistics covering the whole population; but I have been supplied with exact information about a suburb of Georgetown with a population of about 3,000 , and there is no reason to suppose that the results will not apply generally. In this village the death-rate was equal to the birth-rate during the years 1938-44 inclusive. The average infantile mortality during this period was about 250 in a thousand. It rose to more than 350 in 1944. D.D.T. control was introduced in July 1945. By the end of 1947 the birth-rate had doubled, and the infantile mortality had dropped to 67 in a thousand. The population is increasing by 10 per cent annually.

\section{Population and Food Supplies}

As the new methods of preventive medicine spread-and that there will be many more to come no one can doubt-we must expect the world population to grow at an even faster rate than it has done in our life-time, unless famine intervenes. Moreover, it will grow particularly in parts of the world that already have a high density of population, such as India, where the population is now increasing by five million people a year; and Egypt, where there are already 2,000 people to every square mile of cultivated land, and where it pays to have children as they are a source of labour and of profit to their parents at a very early age.

Exactly fifty years have passed since a president of the British Association last warned his audience of the danger of famine. Sir William Crookes was then alarmed at the prospective shortage of wheat. He produced evidence to support his conviction that England and all civilized nations stood "in deadly peril of not having enough to eat". But he qualified his gloomy forebodings by the statement that the chemist must come to the rescue of the threatened communities, and went on to discuss the possibility of the fixation of atmospheric nitrogen. If that were achieved, the future, said Crookes, could take care of itself, and "in days to come when the demand may again overtake supply, we may safely leave our successors to grapple with the stupendous food problem". The chemist did come to the rescue, and the plant breeder too, though not quite in the way that Crookes imagined; and now the day has came when we must grapple again with the problem. We must not encourage the easy thought that some entirely now development in science will solve it quickly; there is nothing in sight comparable with the importance of synthetic fertilizers. There are certainly some interesting investigations in progress, for example, the production of food yeasts from molasses, and of fats by the action of micro-organisms on carbohydrates. All that can reasonably be said about these new developments at present is that they show the need for fundamental research in an almost untouched field. They are very unlikely to lead to a new and substantial source of supply of food within the next thirty years. So far as Great Britain is concerned, we must plan our economy on the assumption that food will be both scarce and dear for many years to come. Its scarcity is obvious to us; its dearness is concealed by a policy of subsidies. I do not criticize the policy. I refer to it only because it tends to hide a state of affairs that should be realized by every thinking man.

One or two years of good harvests in the wheatproducing countries may go far to relieve the present troubles of Europe, and will be of great benefit to us. But the supply of wheat is only part of a larger problem. World food supply will only keep up with demand if the productivity of land is increased, and more land is brought into cultivation. The productivity of land in the United Kingdom is already high; much higher, for example, than in most European countries and in North America. The productivity of labour on the land has increased in recent years much more than the productivity of labour in any other old industry. One man working on the land now produces enough food for twentyfive of the population. New Zealand surpasses all other countries in both respects. It is a land blessed by Nature and improved by science. But few people realize that in our small country we now grow enough food for twice the population of Canada. There is still room for a great advance. There is a consensus of opinion among experts whom I have consulted that the production of food in the United Kingdom could be raised by 20 per cent within five years by a combination of measures, such as the improvement of grasslands, the conservation of grass for winter feeding, the control of pests and weeds, the extended use of fertilizers, and the development of large tracts of marginal land such as exist in the Highlands of Scotland. It is argued that, though this would need considerable capital expenditure, there is no direction in which capital expenditure would yield more certain dividends to the nation, or make a more substantial contribution to the balance of trade.

I find these views convincing. But even if all this were to come to pass, we shall still need to import food for twenty to twenty-five million people unless there is to be a large outward movement of population; and we must not lose sight of the fact that at least twenty million people are added to the population of the world every year, and that it is conceivable that in another seventy years, or even less, the world population will have doubled. Whatever other countries may do, it is our bounden duty, and the only certain way of safeguarding our future so long as we remain a large food-importing country, to develop our colonial territories, particularly the underpopulated African colonies, where the increase in population that would follow the control of disease and the increase of food supply would open fresh markets for international trade. This great task will call for the intensive application of science, in collaboration with other countries. The tale of plant disease in our Colonies, for example, is a sorry one. I shall predict that unless the prevention of disease among plants and animals, and all other scientific problems of the supply of food, are studied on the same kind of scale, by men of similar calibre, as are the problems of human health, chaos and misery will result. Whatever new comforts and luxuries may be provided in future by the advance of physical science, it is on the development of the biological 
sciences that the peace and prosperity of the world will largely depend. Until recently there have been far too few careers open to young biologists outside the field of the medical sciences. There has been nothing corresponding to the Colonial Service, which has offered to young administrators a life of adventure nicely seasoned with economic security. All members of the British Association will therefore welcome the intention of the Government to inaugurate a Colonial Scientific Service, and will hope that the conditions of service will be such as to attract young men of the highest quality.

\section{Challenge of the Times}

We live, indeed, in difficult times. But they are very interesting times; and difficulties are bracing to a nation which has not lost the resilience of youth. We must not get into the way of thinking of our great country as an elderly man who is told by his doctor that if he is very careful of his diet, and avoids all exertion and worry, he may look forward to some years of placid life before he dies. This is a time for adventure; for taking risks. Calculated risks, of course; but not so nicely or so lengthily calculated that they are taken too late. My contacts with universities and with industry are not now so frequent or so close as I should like them to be; but they are enough to convince me that the spirit of adventure in science is as lively as it ever was. It is that spirit which will largely determine the future. Many years hence, when a president of the British Association reviews the progress of the nation from the depths of bankruptcy to new and unsurpassed heights of prosperity and influence, he may well have occasion to refer, as I did at the beginning of this address, to the great influence of the work of a few young men who are now unknown to the public; and he may justly claim that the chief cause of the change was that we had found the right way to combine originality in science with enterprise and speed in its application.

\section{SUMMARIES OF ADDRESSES OF PRESIDENTS OF SECTIONS}

\section{RECENT ADVANCES IN THE STUDY OF THE CRYSTALLINE STATE}

TN his presidential address to Section A (Mathe1 matics and Physics), Sir Lawrence Bragg points out that X-ray analysis of crystals may be said to have attained its majority this year. Its importance has been recognized by the formation of an International Union of Crystallography, and it takes its place with the other branches of science which have unions of their own. Laue discovered the diffraction of X-rays by crystals in 1911; now most universities have an active centre devoted to the investigation of the arrangement of atoms in matter by means of X-ray diffraction. Sir Lawrence has worked in this field from the beginning, and takes the opportunity which this address affords to review what has been accomplished in little more than a generation. $\mathrm{X}$-ray analysis is a typical border-line subject. Its successes are interesting to the chemist, mineralogist, metallurgist and biologist as well as to the physicist, and this is perhaps its most attractive feature.

In X-ray analysis in general, we are seeking to interpret the manner in which a substance diffracts $\mathrm{X}$-rays owing to the spatial arrangement of its atoms. Two mair lines of work may be distinguished. On one hand, there is the analysis of the pattern of the perfect crystal, where the atoms have taken up positions of equilibrium under the influence of the interatomic forces; from the conformation of the structure we can gain a deep insight into the nature of these forces. This study is principally of interest to the chemist, because it presents him with a scale plan of the chemical molecule and of the way molecules or ions are held together by the intermolecular forces to form a solid structure. The results of X-ray analysis have had a profound influence on chemistry and mineralogy and solved many problems. A steady advance has been made in tackling more and more complex molecules, and a stage has already been reached where such compounds as the sugars, strychnine, sterols and penicillin can be analysed, to take a few examples. We would like to pass on to the study of such high complexes as the molecules which form part of living matter-nucleic acids, proteins and others.

The other side of X-ray analysis is concerned with what we might call the 'geography' of atomic arrangement in matter. The perfect crystal is an ideal which is rarely attained. Even if the substance is pure it is composed of a mass of crystals, and we are interested in the size and shape of the crystallites and their growth, in allotropic change, and in their preferred orientation and state of strain after mechanical treatment; if complex, we are interested in the fitting together of the crystallites of different kinds. Metastable structures often exist in which there is partial separation into regions of different composition, while a continuous crystal lattice is preserved though in a distorted form, as in the permanent magnet alloys, in martensite, or in age-hardening alloys. We can study the distortion of the lattice by the thermal waves at high temperatures. Amorphous and semicrystalline matter can be examined. All these aspects of structure are of prime interest to the physicist and metallurgist. They are vitally interesting to the technologist, because the geography of the structure has a profound influence upon its mechanical, electrical and magnetic properties.

In this address, Sir Lawrence reviews the active centres carrying out X-ray investigations in Great Britain ; examples are given of recent work, presenting a picture of what has already been achieved, and indicating the lines of exploration which are now being pursued.

\section{SPECIALIZATION AND CULTURE IN CHEMISTRY}

$\mathrm{P}$ ROF. JOHN READ, president of Section B (Chemistry), deals with some of the problems of increasing specialization in chemistry. The growing burden of new knowledge in chemistry, as in science generally, has created many new problems for the student, teacher and research worker. These problems are largely bound up with the growth of 